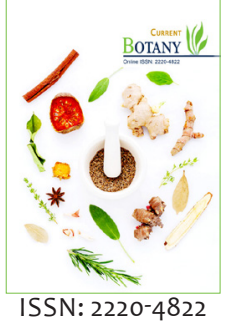

Received: December 27, 2019

Revised: May 14, 2020

Accepted: May 22, 2020

Published: June 1, 2020

*Corresponding Author:

S. Elumalai

E mail: ananandal@gmail.com

\section{Global health concern of cyanotoxins in surface water and its various detection methods}

\author{
M. Ramya', A. Umamaheswari', S. Elumalai ${ }^{2 *}$ \\ 'Department of Plant Biology and Plant Biotechnology, Presidency College (Autonomous), Chennai-600 005, Tamil Nadu, \\ India, ${ }^{2}$ Department of Biotechnology, University of Madras, Guindy Campus, Chennai-600 025, Tamil Nadu, India
}

\begin{abstract}
Water is an absolutely required resource for life, nourishment which now became a worldwide threat due to unenviable changes in an environment that are mainly instigated by human influence. The foremost progressions intensify the consequence, permitting the growth of cyanobacteria that is blue-green algae in surface water. CyanoHABs (Cyanobacterial Harmful Algal Blooms) occurred in its adopting nature according to the temperature fluctuations in the earth. In this study, a basic introduction to cyanotoxins as well as the entanglement of public health that includes the route of exposure, health effects, and the pervasive impact of cyanotoxins and alleviation efforts in the water bodies along with the toxicosis were appraised. Cyanobacterial toxins with the conditions like hepatotoxicosis (liver toxicity), neurotoxicosis (brain toxicity) and gastrointestinal disturbances, respiratory and allergic reactions were reviewed. Their detection process and the treatment techniques with various physicochemical methods and bioassay methods were also reviewed. The assorted techniques and their combinatorial detection methods that are adopted in this review will help us to eradicate the toxins from the surface water.
\end{abstract}

KEYWORDS: Cyanobacteria, cyanotoxins, Bioassay, physicochemical methods, hepatotoxins and neurotoxins

\section{INTRODUCTION}

The algae, which are microscopically small, unicellular organisms form colonies and thus varies in sizes visible as minute green particles [1]. The term cyanobacteria are similar to algae in size, unlike other heterotrophic prokaryotes, they perform photosynthesis mechanism exhibit blue-green and green pigments. Harmful algal blooms are termed as HABs which reported globally due to several factors [2,3]. Predominantly because of anthropogenic activities like agricultural runoff, insufficient sewage treatment, industrial and uncontrolled use of fertilizer known as eutrophication [4]. Due to the excessive accumulation of nutrients in water bodies, causes an extensive growth of algae and cyanobacteria. Hence the water quality becomes diminished, which are hazardous to aquatic animals, plants and also implicated in humans $[5,6]$.

Moreover, recent studies proved that anthropogenic global warming influences the toxic generating cyanobacteria also identified as cyanotoxins that exist over a prolonged period of time, a gradual increase in population, and geographical distribution [7]. The toxin discharged by cyanobacteria plays both deleterious and advantageous influences [8]. When centering on a profitable perspective, the compounds that are transmitted by blue-green algae are vital within the province of pharmaceutical and biotechnology intrigued.

The pharmacological properties of certain cyanobacteria on people incorporate anticancer, anti-inflammatory, and antibiotic bustles. It also plays a role in predator-prey models like their toxicity would be a nightmare to the dangerous species. This character sometimes useful to the ecosystem balancing. And at the same time, attributable to certain natural conditions can able to tolerate various climatic changes associated with anthropogenic impacts $[9,10]$. CyanoHABs can proliferate exponentially on surface waters and form complete blooms when the circumstances are favorable. These revolutions give rise to an increase in $\mathrm{PH}$, temperature, oxygen demand, and accessibility of nutrients, especially the accumulation of phosphorous, nitrogen, etc. [11]. When the algae get perished, it utilizes oxygen completely and hence water becomes anoxic (Oxygen deprivation). This transpires exclusively after the complete growth of algal [12].

The physical constituents as well as chemical constituents blatantly enhance the development rate of poisonous algae. 
There is a rich phosphorus backlog in the "Missisquoi Bay" that causes the complete development of algae [13]. Cyanobacteria from nine hot water/thermal springs located in the northwestern Himalayas. This unique adaptation of blue-green algal growth in consortium with other microbial community exhibit resistivity towards a thermal gradient of $74^{\circ} \mathrm{C}$ which is an upper threshold for photosynthesis.

In India, only a few studies carried out on cyanobacterial diversity from thermal/ hot water spring [14,15]; from Bihar [16,17]; from Uttarakhand and from West Bengal [18-22] from the western part of the country [23].

The cyanobacterial toxins (toxicosis) that include hepatic, neurotoxicosis, respiratory disorders, disruptions in both stomach and intestine (gastrointestinal disorder) and certain hypersensitivity reactions. So far these studies were unproven hence further studies needed [24].

In freshwaters, repeatedly acquired toxin-producing cyanobacterial strains are Microcystis, Anabaena, Nodularia, Planktothrix, Aphanizomenon, Cylindrospermopsis and Lyngbya etc. These colonizer or filamentous cyanobacteria generate a multiplicity of chemically and biologically distinctive toxic components such as hepatotoxins (microcystin and nodularin), neurotoxins (anatoxins and saxitoxins), paralytic shellfish toxins (as emitted by Aphanizomenon), cytotoxins (cylindrospermopsin) and dermatotoxins (lipopolysaccharides) [25]. The molecular structure, source of toxins and its mode of actions of the above said strains are discussed below in Table 1.

\section{Microcystins and Nodularins: The Cyclic-Peptide}

Nodularin, as well as microcystin poisons, are as often as possible happening with liver poisons $\left(\mathrm{LD}_{50}\right.$ (i.p) $50-1000 \mu \mathrm{g} / \mathrm{Kg}$ ) [26]. The prevailing toxin of microcystin is specially unearthed in sources as mentioned in Table 1. As far as the toxin "Nodularin" is concerned, it could be found merely in "Nodularia sp" [27]. Polar compounds of microcystins having free carboxylic acid in its chemical composition and there will be arginine that occurred frequently. Non-ribosomal biosynthesis can take place with the aid of the MCS (microcystin synthetase) enzyme which is having multifunctional properties. These toxins are organspecific, in which the cell membranes get affected by carrier molecule (organic anion). That is why the Liver influenced effectively due to the penetrability of such a molecule. In general, the peptides from a similar family are hydrophobic and usually do not own the ability to diffuse via the vertebrate cell membrane and hence they depend on ATP as a carrier molecule.

\section{Anatoxin: Secondary Amine Alkaloids and Guanidium Methyl Phosphate Ester}

Anatoxin causes an acute neurotoxic disorder. When living things exposed to the neural toxin Anatoxin (a)/ a(s) (i.p injection in mice-LD ${ }_{50} 20-250 \mu \mathrm{g} / \mathrm{Kg}$ b.wt) leads to immediate death by provoking expeditious tightening or relaxation of muscle fibers, Ataxia (an abnormal muscular movement), and hypoxemia (Paralyzed prodrome associated with respiration) [28]. Through the receptor "nAChRs" ("nicotinic acetylcholine") toxin enters into the cell, and the receptor imitates "Ach" (Acetylcholine) which is a natural ligand that amends the physical and biological responses with respect to neurons. The binding of anatoxin to the receptor is irrevocable and cannot be able to breakdown by the enzyme called "Ach esterase enzyme". The toxins which are accountable for the neuro-muscular blockades are Anabaena flosaquae and Oscillatoria species.

\section{Saxitoxin: Alkaloid}

In an existing freshwater/ brackish water, carbamate alkaloid compound present in the saxitoxin. These compounds are responsible for toxicity that is liberated by certain strains like Anabaena circinalis, Aphanizomenon sp, Cylyndrospermopsis raciborskii, and Lungbya wollei [29]. They block voltage-gated sodium channels ( $\mathrm{LD}_{50}$ (i.p): $08-10 \mu \mathrm{g} / \mathrm{kg}$ ) and causing paralysis by disrupting the integral membrane protein of neurons. The SXTs i.e, Saxitoxins also entitled as (PSP) Paralytic Shellfish Poisoning. SXTs or PSPs enter humans via aerosol either through anthropogenic/ natural sources [30].

Table 1: Cyanobacterial Toxicity and its mode of action from Fresh and Brackish water

\begin{tabular}{|c|c|c|c|c|}
\hline Toxin & Molecular structure & Sources & Modes (S) of Toxicity & Reference(s) \\
\hline Nodularia & Cyclic pentapeptide & Nodularin & $\begin{array}{l}\text { Hepatotoxic tumor } \\
\text { promoters, PPase } \\
\text { Inhibitors }\end{array}$ & {$[31]$} \\
\hline Microcystin & Cyclic heptapeptide & $\begin{array}{l}\text { Microcystis, Anabaena, } \\
\text { Nostoc, } \\
\text { Oscillatoria }\end{array}$ & $\begin{array}{l}\text { Hepatotoxic tumor } \\
\text { promoters, PPase } \\
\text { Inhibitors }\end{array}$ & {$[32]$} \\
\hline Anatoxin-a & Secondary amine alkaloid & Anabaena & $\begin{array}{l}\text { Neurotoxic, } \\
\text { Depolarizing } \\
\text { Neuromuscular block }\end{array}$ & {$[33,34]$} \\
\hline Anatoxin-a(s) & $\begin{array}{l}\text { Guanidium methyl } \\
\text { phosphate ester }\end{array}$ & Anabaena & $\begin{array}{l}\text { Neurotoxic, } \\
\text { Cholinesterase } \\
\text { Inhibitors }\end{array}$ & {$[35]$} \\
\hline Saxitoxin & Alkaloid & Aphanizomenon & $\begin{array}{l}\text { Neurotoxic, Sodium } \\
\text { channel blockers }\end{array}$ & {$[36,37]$} \\
\hline LPS & Lipopolysaccharides & $\begin{array}{l}\text { Microcystis, } \\
\text { Oscillatoria }\end{array}$ & $\begin{array}{l}\text { Toxic shock, } \\
\text { gastroenteritis, } \\
\text { Inflammations }\end{array}$ & [38] \\
\hline
\end{tabular}




\section{LPS: Lipopolysaccharide (Irritant toxin)}

Recent studies proved that the lipopolysaccharide from filamentous cyanobacteria involved in causing various health issues such as irritations on the skin, hypersensitivity, respiration dysfunction, gastric disorder, fever, etc. [39]. The LPS toxins are emitted by Microcystis and Oscillatoria that triggers chemokines and eicosanoids that invigorate aggravation in neurons by emitting distinct proteins [40].

\section{Action mechanism of Cyanobacterial toxicity}

The huge fragment of the toxic peptides from the MCs and NOD are aquaphobic and depend on ATP as a carrier [41]. In Rat liver, bile acid acts as a carrier for poisonous proteins that are constrained to organs and impact their cell layers. The toxic cells from different strains are lysed within the digestive tract and permeate into the bloodstream. Afterward, it is being brought to hepatocytes, which quell the protein phosphatase movement assistant leads to the excessive phosphorylation within cells that destroy the hepatic cells [42].

The microcystin and Nodularins are two distinct inhibitors of catalytic protein phosphatase (PPase) enzyme with subunit 1 and $2 \mathrm{a}(\mathrm{PPl}$ and $\mathrm{PP} 2 \mathrm{~A})$ containing exclusive substrate binding ability in liver cells [43]. These proteins correlated with PK (protein kinase) in the regulation of several phosphorous groups in protein. When focusing on Neurotoxin, the alkaloid neurotoxin anatoxin-a (antx-a) is a potent postsynaptic depolarizing neuromuscular blocking agent. Depending on the pathogenicity of a species, and the number of poisonous substances instigates immediate death. This antx-a poisoning progression causes muscle fasciculation, decreased movement, abdominal breathing, and sudden death. No known therapy exists for antx-a, although respiratory support might allow sufficient time for detoxification and recovery of respiration control.

Saxitoxin are also called paralytic shellfish poison (PSPs) which are produced by species of the genera Aphanizomenon, Anabaena, Lyngbya, and Cylindrospermopsis. This Saxitoxin block neuronal transmission when bonded the voltage gated $\mathrm{Na}+$ channel nerve cells [44]. These potent voltage-gated sodium channel antagonist can cause numbness, paralysis and even get to the mammals through respiratory block, channel opening and sodium channel blockers causes muscle paralysis and death by respiratory arrest. This saxitoxin transformation in shellfish update carried out through epimerization, decarbonylation reductive elimination.

In the year august 2013, fifteen livestock died around 2 fishponds in Kentucky. And within the same year, the dog became fatally ill after swimming in clear Lake California, 4 weeks later, the dog with clinical signs was observed. The samples from the water were collected and tested. It showed protein phosphatase inhibition activity, i.e.PPl. The subsequent evaluation was performed using liquid chromatography-mass spectrometry (LC-MS/MS) which detected microcystin LR, - RR, LA, LF but failed to detect YR [45].
The Neuro and Hepatotoxicity Consequences on Human and Aquatic Biota

Within the central portion of India, out of fourteen microcystisdominant bloom of cyanobacteria, three MC's were found to be poisonous. [46]. Findings divulged that the dominance of fourteen different genera comprised of distinctive groups of microcystis (MC) from the towns of Kundam, Jabalpur, and Shahpura was discerned to be toxic to the crustacean zooplankton "Moina Macrocopa" at the concentration level more prominent than $282 \mu \mathrm{g}$ bloom dry weight $/ \mathrm{ml}$. Bloom samples from ponds and lakes of Jabalpur, Dindori, Mandler, Seoni and shahdol districts were gathered and scrutinized for microcystin harmfulness on the premise of an intense poisonous quantity (ca.LDl00) i.e 70,100 and $260 \mathrm{mg}$ dry wt/ $\mathrm{kg}$ of kundam, Jabalpur and Shahpura bloom material. When exposed to Lake Bloom, it appeared a serious necrotic injury within the hepatic tissues.

Subaqueous plant "Ceratophyllum demersum" when susceptible to CyanoHABs, showed reduced growth at the dosage of $1.0 \mu \mathrm{g} / \mathrm{L}$ of MC-LR(microcystin) after six weeks, while at a concentration of $5 \mu \mathrm{g} / \mathrm{L}$ of MC-LR showed reduced growth after 3 weeks [47]. An invasive organism Zebra mussel (Dreissena polymorpha) is subaqueous habitats, originated from Russian lake. They pervade to other countries either by ship/pleasure crafts due to their capacity of clean water impurities and easily take up toxic cyanobacteria. In another way, this has been used as a poultry feed. After the intake of microcystin from Microcystis aeruginosa, there will be a loss of net energy balance and their scope of growth was significantly reduced. [48].

\section{Health Consequences of Cyanobacterial Toxins}

In addition to human toxicity, aquatic plants, humans and other invertebrates, cyanoHABs can also be toxic to some fishes, by causing liver necrosis, impaired tissues, due to accumulation of toxins (microcystin) in their organs that passes via gills [49]. As proved by UK histopathological investigations of fish deaths during cyanobacterial blooms occurred due to the damage to gills digestive tract and liver. This might be due to the high $\mathrm{pH}$ induced by cyanobacterial photosynthesis activity prior to bloom collapses together with the highest level of ammonia arising from the decomposition of the cyanobacteria. However, the microcystin uptake happened through damage of organs and thus led to liver necrosis. Fishes especially phytoplanktivorous species that can be exposed to MC either by feeding or toxins pass through the gills during its breathing.

The Hirakud reservoir in Sambalpur was built fundamentally to generate electricity but it is additionally utilized for the water systems, fisheries, and drinking water which is now completely polluted by manufacturing plants in different wetlands of Sambalpur areas, and its neighboring Jharsuguda area Odisha. Underneath the Hirakud Dam, they found 37 species of cyanobacteria belonging to 17 genera. According to the literature study, seven genera are found to be toxic including Anabaena, Microcystis, Nostoc, Gloeocapsa, Lyngbya, Oscillatoria, and 
Phormidium. These cyanotoxins are dangerous to human and animal health who is drinking the water from these lakes. [50,51] Out of 17 genera, the potential toxin-producing genera as said earlier, produces Microcystin, Anatoxin-a. Anatoxin-a(s) and, saxitoxin. Depending upon the effects, they further classified as a hepatotoxin, neurotoxic and Dermatotoxin [52].

Also, more and more attention to be paid for the presence of cyanobacterial toxins in consumer products which include dietary supplements produced from blue-green algae (BGA), fish or seafood [53]. This tends to be more problematic than consuming $1.5-2$ 1/day water, whereas BGA intake would be $20 \mathrm{~g}[54]$.

In 1994, at Sweden River, there was heavily populated cyanobacterium Planktothrix sp., causes toxicity. The illegitimate usage of river water from a sugar factory from a cross-connection between potable to non-potable river water for a dubious period of hours caused serious health issues. 121 of 304 inhabitants of the village, including animals got affected with hepatotoxicity by microcystin. The samples were tested before and after the incident happened [55]. Neurotoxins that cause Parkinson's, as well as Alzheimer's disease and some, are caused by cyanobacterial species. Alzheimer's disease and Dementia increased drastically in China from 3.7 to 9.2 million in the year 1990 to 2010 [56].

\section{Bioassay for the Detection of Cyanotoxins}

There are numerous natural approaches (Table 2) established to spot toxins generated by cyanobacteria based on their interactions, immunological response, and several enzymatic actions.

\section{Bioassay using Microbes}

Toxicity can be detected by the use of microbes helps in detecting low amounts with in short time, though this idea might not be very suitable for detecting toxicities presented by cyanobacteria. Bioassays using bacterial community for detection of cyanobacterial toxins have been confined only to the detection of toxic extracts from cyanobacteria and not to pure toxins such as microcystin-LR.

Upon tested various solvents for the strains of Cylindrospermum majus, Oscillatoria, Calothrix gracilis, and Nostoc, n-hexane solvent restrained these microbial clusters at the concentration of $100 \mu \mathrm{g} / \mathrm{ml}$, and when experienced distinctive extracts for the cultures such as Pseudanabaena catenata, Anabaena variabilis, and Gloeocapsa caldariorum, menthanol extract repressed the microbial growth of Bacillus subtilis with the concentration extend from 1.4 to $70 \mu \mathrm{g} / \mathrm{ml}$. [57]. The Limnothrix redekei also inhibits the growth of Staphylococcus aureus and Micrococcus flavus with the concentration of $50 / 100 \mu \mathrm{g}$ of the isolated substances per paper disk. [58]. The Pseudomonas $(50 \mu \mathrm{g} / \mathrm{ml})$ were possibly involved in the degradation of MC-LR. The use of bacterial strains, however, needs further investigations [59,60].

\section{Bioassay Using Invertebrate Animals}

Daphnid bioassay used to look at the harmfulness of $\mathrm{MC}$ and NOD. The harmfulness finding of microcystin at the dose adapted from $16.4 \mu \mathrm{g} / \mathrm{g}$ body weight to $1226 \mu \mathrm{g} / \mathrm{g}$ body weight [61]. Daphnid bioassays are not well suitable for diagnosing a lesser quantity of toxic peptide. The eggs of Artemia salina are commercially accessible and are viable for years beneath subzero temperatures. Nevertheless, the toxicity towards all divergences of neural toxin (anatoxins, saxitoxins), liver toxin (nodularin, microcystin) as well as protease inhibitors, have not been flaunted towards Artemia bioassay (brine shrimp eggs) which restricts the usage of this particular bioassay [62].

The mosquito (larvae and adult) has too found to be as conceivable bioassay approaches against cyanotoxins [63]. Larvae of Aedes aegyptii have been found to be influenced by neural toxins (anatoxin-a) and hepatotoxins (Microcystis strains coupled with Oscillatoria strains). Distinct concentrations related to 0.5 to $17.5 \mathrm{mg}$ of desiccated cyanobacteria/mL were exploited in assays. The toxicity of these strains was evident only after 48 hrs of incubation period and the strains killed all larvae efficiently $(\mathrm{P}<0.05 / \mathrm{P}<0.001)$.

Adults of Culex pipens were found to be sensitive towards MC-LR when injected. Due to the difficulties of handling this organism, both mosquitoes were relatively sensitive, but have not been widely adopted.

Similarly, [64] adult house flies (Musca sp.) with the concentration 0.5 and $3.7 \mathrm{mg} / \mathrm{kg}$, diamond-back/Cabbage moth (Plutella sp.) $1.0 \mu \mathrm{g} \mathrm{cm}^{2}$, and cotton leafworm (Spodoptera sp.) of 4.7 and $13.1 \mathrm{mg} / \mathrm{kg}$ concentration, were found sensitive when administered with purified toxins via treated leaf towards MCLR. Positive results were observed when compared with other toxicity results. The handling of flies is strenuous and needed microinjection that is difficult to administer [65].

Except for the handling difficulties of an insect, fruit fly (Drosophila melanogaster), can detect microcystins successfully in bloom samples and can be maintained in the laboratory, with no requirement of special equipment. The toxin $\left(\mathrm{LC}_{50} 0.8 \mathrm{~d} . \mathrm{w} / \mathrm{mL} \pm 0.3\right.$ scale of $95 \%$ confidence interval) can be administered orally to a 24 (hour) pre-starved fruit fly by spotting a sample along with sucrose on filter discs [66]. Drosophila has been utilized to experiment with the dietary ingestion of BMAA toxin ( $\beta$-N-Methyl amino-L-Alanine) which is exuded by the "Nostoc sp" provokes brain malfunction in aged adult flies and in females, it revealed diminished fertility. No efficacious clambering actions were scrutinized in flies when nourished with 8 or $10 \mathrm{mM}$ of BMAA toxin [67].

\section{Bioassay Using Vertebrate Animals}

Mouse bioassay is the most preferred bioassay for testing microcystins. The total toxicity caused by cyanobacteria can be estimated in drinking water supplies using mouse bioassays. Swiss Albino Mouse (Male) is the commonly used strains for 
testing Cyanobacterial toxins (oval dose $\mathrm{LD}_{50}$ used 5000 $\mu$ g toxin $/ \mathrm{kg}$ body weight) [68]. The major drawback in using mouse assay is the need for an animal house facility for rearing the animals for routine experiments, ethical clearance and microcystin-LR may mask other symptoms.

A desert locust (Schistocerca gregaria) based bioassay are easy to handle and samples can be administered by injecting low volumes $(10 \mu \mathrm{l})$. The use of locusts is very simple, ethically acceptable, broad-specificity functional bioassay, for the monitoring of saxitoxins and other paralytic shellfish toxins. [69].

\section{Bioassay Using Cell Cultures}

For hepatotoxicity testing, the fish cell line is most preferable [86]. Use of hepatocellular carcinoma of the topminnow poeciliopsis lucida (PLHC-1) and Rainbow trout Oncorhynchus mykiss (RTG-2 fibroblast) was chosen for treating hepatotoxins produced by Microcystin which was isolated from bloom. These cell line techniques drastically reduce the size of the cell leads to apoptosis. Whereas neurotoxin, neuroblastoma cell line bioassay was used to test saxitoxin $[70,71]$.

For neurotoxins assays, a neuro receptor-binding assay was developed earlier for saxitoxins, a neuroblastoma cell line method for sodium $(\mathrm{Na})$ channel blocking activity has also become an advanced technique for the analysis of neurotoxins [72]. Again, the use of cell cultures for toxicity needs further experiments before a universal cell line can be adopted for all known cyanotoxins in freshwaters. [73-75].

\section{Bioassay Using Plants And Plant Extracts}

Microcystins produced by cyanobacteria exhibit secondary metabolites shows algicidal or herbicidal properties. Bioassay using Anacystis, Phormidium, Plectonema and Chlorella has been used to investigate algicidal effects posed by Oscillatoria. Little work has, however, been done on establishing a simple, cost effective and sensitive plant based bioassay for the detection of cyanotoxins in drinking water.

The effect of a microcystin-LR extract on the growth of Lepidium sativum over 6 days. Exposure to $10 \mu \mathrm{g} \mathrm{L-1} \mathrm{microcystin-LR}$ concentration resulted in a significant decrease in root and leaf lengths as well as fresh weights of seedlings when compared to the controls. The use of this bioassay needs vast exploration. Pollen germination was inhibited by cylindrospermopsin between 5 and $1000 \mu \mathrm{g} \mathrm{ml}-1$. The inhibition of tobacco pollen germination may be amenable for development as a bioassay for cylindrospermopsin, although this would require a pre-concentration step for the monitoring of environmental samples. [76,77].

\section{Enzyme Linked Immunosorbent Assay (ELISA)}

This bioassay was sensitive to sub-nanogram levels ( $\mathrm{lng} / \mathrm{ml}$ ) of nodularin and microcystin. The method has also been used successfully for quantitation of microcystins in environmental samples that identifies approximately $0.2 \mu \mathrm{g} / \mathrm{l}$ and $0.25 \mu \mathrm{g} / \mathrm{g}$ [78]. The novel ELISA technology used to detect free saxitoxin on the basis of non-covalent immobilization technique which is demonstrated on polyclonal rabbit anti saxitoxin antibody and compared with conventional ELISA of saxitoxin using saxitoxin bovine serum albumin conjugate as the coating antigen. This technique has restriction usage because of antibodies against all possible variants of hepatotoxins and anatoxins are still not available. Moreover, the ELISA kits and consumables are far more expensive than any other bioassay system [79].

\section{Treatment for the Removal Of Toxin Producing Cyanobacteria}

There are distinct approaches that can be adopted to treat contaminated water. At first, colonies of cyanoHABs/ cyanotoxins have to be confiscated carefully from fresh and brackish water without affecting the cells. Since the toxicity within the cell may be detonated in the water. Methodology for removing toxic cells, such as settling, coagulation, filtration, and flocculation can be performed as mentioned in Table 3 [80]. The Coagulation method/flocculation method along with alum is acknowledged around the world. The procedures might not give a satisfactory result [81].

When compared to ultrasonic removal, Ultrafiltration technique is most reliable for the removal of Microcystin which remove more than 99.99\% [82]. Microcystins can be directly removed with the help of naturally existing chlorine using electrochemical method. In-situ electro generator active chlorine from chlorine in water completely remove the microcystin. [83]. Chlorine treated water was not toxic to Mouse as shown by the histological examination except when treated Cylindrospermopsis.

Forty-six percentage of toxicity deduction was perceived with heat-treated L. rhamnosus strain GG for microcystin$\mathrm{LR}$ as well as the Bifidobacterium sp at $0.5 \mu \mathrm{g} / \mathrm{ml}$ intensity at $35^{\circ} \mathrm{C}$ after $7 \mathrm{~h}$ of incubation $[84,85]$. The activated carbon is the another method for the potential removal of toxin from water source [86] which showed total elimination of cyanobacteria under low concentration of hepatotoxins through the combined action of pre ozonation and absorption of powdered activated carbon. Wood based carbon absorb more Microcystin than the coconut-based carbon [87].

Bioassay methods are mandatory to keep the toxin level below the safe level guidelines proposed by WHO. However, analytical techniques such as reverse phase HPLC and MALDI- TOF are necessary to identify and quantify the cyanotoxins in the water bodies [88]. Once the toxin identified using the above techniques, the appropriate bioassay can be chosen based on the biological activity of toxins as well as the facilities available. 
Table 2: The Overall View of Bioassay Methods and Its Reliability

\begin{tabular}{|c|c|c|c|c|}
\hline Methods & Toxins & Cost & Remarks & Reference \\
\hline \multicolumn{5}{|c|}{ Bioassay using Vertebrate } \\
\hline Mouse & $M, N, A, A(s), C, S$ & Medium & $\begin{array}{l}\text { Require } \\
\text { permission for } \\
\text { license }\end{array}$ & {$[89]$} \\
\hline \multicolumn{5}{|c|}{ Bioassay using Invertebrates } \\
\hline Brine Shrimp & $\mathrm{M}, \mathrm{N}$ & Medium & Availability of commercial kit and Expensive & [90] \\
\hline Daphnid & $\mathrm{M}, \mathrm{N}$ & High & $\begin{array}{l}\text { Culturing techniques are } \\
\text { labor intensive }\end{array}$ & {$[91]$} \\
\hline Thamnotox & $M, A, C$ & Medium & $\begin{array}{l}\text { Availability of Commercial kit. } \\
\text { Need full assessment for cyanotoxin evolution }\end{array}$ & [92] \\
\hline Mosquito & M & Medium & Handling is difficult. & [93] \\
\hline Fruit fly & $\mathrm{M}, \mathrm{N}$ & Low & Culturing is easy & [94] \\
\hline Locust & S & Low & Easy Handling & [95] \\
\hline $\begin{array}{l}\text { House fly } \\
\text { Bacterial }\end{array}$ & S & Low & Administer of toxin is difficult & {$[96]$} \\
\hline Microtox & $\mathrm{M}, \mathrm{N}$ & Low & No connections. & [97] \\
\hline Serratia sp & $\mathrm{M}, \mathrm{S}$ & Medium & Poor Connections. & [98] \\
\hline Biochemical & $\mathrm{M}, \mathrm{N}$ & & Sensitivity is high. & {$[99]$} \\
\hline \multicolumn{5}{|l|}{ Assay } \\
\hline \multicolumn{5}{|l|}{ PPase inhibition } \\
\hline 1. Radioactive & & Low & $\begin{array}{l}\text { Require special } \\
\text { Facilities. }\end{array}$ & {$[100]$} \\
\hline 2. Calorimetric & & Low & Enzyme need to be purified. & [101] \\
\hline AChE & $A(s)$ & Low & $\begin{array}{l}\text { Only available alternative bioassay for } A(s) \text { May react with } 0 \text { P3 } \\
\text { Pesticides }\end{array}$ & {$[102]$} \\
\hline ELISA & & & Very Sensitive & [103] \\
\hline \multicolumn{5}{|l|}{ Technique } \\
\hline 1.Polyclonal & $\mathrm{M}, \mathrm{N}$ & Low & $\begin{array}{l}\text { Variant may } \\
\text { vary for the } \\
\text { reaction }\end{array}$ & [104] \\
\hline 2. Monoclonal & $\mathrm{M}, \mathrm{N}$ & Low & $\begin{array}{l}\text { Variant may } \\
\text { vary for the } \\
\text { reaction }\end{array}$ & [105] \\
\hline 3. Polyclonal & S & Low & $\begin{array}{l}\text { Cross } \\
\text { reactivity may vary and does } \\
\text { not detect } \\
\text { C-toxin }\end{array}$ & {$[106]$} \\
\hline \multicolumn{5}{|c|}{ Mammalian Cell Line Culture } \\
\hline 1.Hepatocyte & $\mathrm{M}, \mathrm{N}$ & Medium & Sensitive but Rapid bioassay. & [107] \\
\hline 2.V79 fibroblast & $M^{\prime}$ & High & $\begin{array}{l}\text { Some false } \\
\text { Negative results observed. }\end{array}$ & {$[108]$} \\
\hline 3. Neuroblastoma & $\mathrm{S}$ & High & Careful standardization needed. & [109] \\
\hline
\end{tabular}

AChE: Aetylacholinesterase; M: Microcystin; N: Nodularin; A: Anatoxin A(s)/(s); C: Cylindrospermopsin; S: Saxitoxin

Table 3: Treatment measures

\begin{tabular}{lll}
\hline S.No. & Traditional method & Modern method \\
\hline 1. & Screening & Bioassay Method \\
2. & Settling & Removal of Dissolved Toxin \\
3. & Filtration & Ultrafiltration, Nano filtration, reverse \\
& & osmosis Fact sheet \\
4. & Disinfection steps & Ozonization, UV, chlorine dioxide \\
\hline
\end{tabular}

The toxin detection is equally important in treated waters for monitoring purposes [110]. Focused screening is presently well built up as a fruitful hit era methodology. With focused screening, it ought to moreover be conceivable to utilize a measure that's more fitting, instead of one that works well on an expansive scale [111]. Daphnids and Shrimps are the two excellent models used in bioassays because of their sensitivity for the changes in water chemistry and are inexpensive and simple to cultivate in an aquarium.
Biochemical tests and ELISA methods are more precise and useful for waterworks and most of the toxin forms can be identified in raw as well as treated water in very short time. However, such methods have limited implications when the compounds other than toxins (microcystins) are present such as protease inhibitors along with the toxins [112].

Though, every method has its own limitation, a combination of bioassays can be adopted in cases where more than one type of toxin is suspected, or where one technique is not sufficient to identify all the variants. So many methods are adopted worldwide for the removal of toxins in raw water. Since most the methods discussed effectively remove toxins from the raw water, techniques in which no external chemical is added to the water, should be adopted.

Biological sand filtration and river bank filtration are some of the methods which not only effectively remove cyanotoxins 
Table 4: Physicochemical method for the detection of toxicity from cyanobacterial species

\begin{tabular}{|c|c|c|c|}
\hline Methodology & Personal cost & Remarks & Reference \\
\hline \multicolumn{4}{|c|}{ Microystins and Nodularin } \\
\hline HPLC- PDA & Low & UV spectra can give tentative id & [113] \\
\hline LC/MS & Medium/low & A number of different interface; mass confirmation; can have PDA & {$[114]$} \\
\hline TLC & Medium & Qualitative; requires standards and further confirmation of toxins & [115] \\
\hline MMPB & Medium & Detection by GC-MS or LC-MS detects total microcystin/ Nodularin & {$[116]$} \\
\hline MALDI & Medium/low & Initially poor but recent developments have improved accuracy & [117] \\
\hline CE-MS & Medium & Requires further development but has future promise & {$[118]$} \\
\hline NMR & Medium/high & Can characterize cyanotoxins; needs mg quantities and expert interpretation & [119] \\
\hline \multicolumn{4}{|c|}{ Anatoxin a, Homoanatoxin a } \\
\hline HPLC-PDA & Low & Characteristic UV-spectra & [120] \\
\hline GC-MS & Low & Characteristic ion spectra & {$[121]$} \\
\hline $\mathrm{GC}-\mathrm{ECD}$ & Low & Requires sample cleanup & {$[122]$} \\
\hline LC/MS & Medium/low & Sensitive and specific & {$[123]$} \\
\hline \multicolumn{4}{|l|}{ Anatoxin a(s) } \\
\hline $\begin{array}{l}\text { HPLC } \\
\text { Cylindrospern }\end{array}$ & Low & Very poor chromophore, not suitable for routine detection. & [124] \\
\hline HPLC-PDA & Low & Lack of available standards; give characteristic UV spectra. & $\begin{array}{l}{[125]} \\
{[126]}\end{array}$ \\
\hline \multicolumn{4}{|l|}{ Saxitoxin } \\
\hline HPLC-PRE & High & Preinoculum derivatization; poor stability of derivatives. & [127] \\
\hline HPLC-POST & Medium & Three solvent systems required to analyze for all variants & [128] \\
\hline LC/MS & Medium/low & Best method for all variants but equipment cost can be prohibited & {$[129,130]$} \\
\hline CE-MS & Medium & Poor detection, need further development & [131] \\
\hline
\end{tabular}

and other toxic substances from water, they are also cheap as well as environment friendly methods [132]. It should be however, noted that some biological control program should be introduced to the water reservoir, so that toxic cyanobacterial blooms can be controlled and the aquatic ecology can be maintained. Various studies showed that some species of aquatic grazers consume toxic cyanobacteria without getting affected by it.

Another approach for biological control of toxic cyanobacteria may be the application of allelopathic interactions between a toxic and non-toxic cyanobacteria. Algicidal compounds from cyanobacteria such as one from Oscillatorialaete-virens, whose algicide effectively eliminates and detoxicify Microcystis blooms; yet lack presence of any type of toxic metabolite [133]. It can be introduced to the water reservoir. However, strains should be introduced only after proper screening for non-production of other toxic metabolites. Genetically modified strains, which lack toxin-producing genes, may provide a better solution in this regard. The biological control of toxic cyanobacterial bloom will not only provide support to the waterworks, but will help in protecting the environment too.

\section{Analysis of Physicochemical Parameters for Cyanotoxins}

Physicochemical analysis of Cyanotoxins is recommended to check cyanobacterial species composition and to determine the existence and quantification of the toxins in a sample. Rapid screening for the large quantities of samples also necessary for the frequent monitoring of water where the toxin is well entrenched. The analytical methods are required to utilize the properties like the molecular weight of a toxin, reactivity held with a functional group of a molecule and chromophores. The analytical method is also necessary to identify the cyanotoxins detection. The suitable methods are adopted and discussed in the Table 4.

\section{CONCLUSIONS}

CyanoHABs are the growing concern in surface water, which instigates health-associated stake among human, aquatic, domestic, and wild animals. In order to eradicate these threats, numerous methods are espoused globally for the exclusion of toxic compounds from fresh and brackish water In order to understand the pathogenicity of a toxin, some of the physicochemical techniques, biochemical assays, and ELISA techniques were adopted. This helps to determine and quantify cyanotoxins which cause neural dysfunction, liver disorders, stomach and skin related issues. For the removal of contaminants from surface water, some of the traditional methods like filtration, screening, and settling are wildly adopted. However, strategies towards effective removal of cyanobacterial bloom have not been substantiated in field environs. So, several biological control programs like aquatic grazers that consume cyanotoxin, and allelopathy interactions among toxic and non-toxic cyanobacteria, which are properly screened can be established in the water reservoirs along with the traditional treatment. So that the cyanotoxins can be diminished/removed completely in the aquatic ecology and maintained further. GMS (Genetically Modify Strains might provide better treatment in this regard. Despite every methodology, there will be some kind of limitations. So, the combination of various bioassay treatments can be adopted for the diversified toxins.

\section{REFERENCES}

1. Kaebernick M, Neilan BA. Ecological and molecular investigations of cyanotoxin production. FEMS Microbiology Ecology. 2001; 35(1): 1-9. 
2. Blaha L, Babica P, Marsalek B. Toxins produced in cyanobacterial water blooms - toxicity and risks. Interdisciplinary. Toxicology, 2009; 2(2)

3. Donald Anderson. HABs in a changing world: a perspective on harmful algal blooms, their impacts, and research and management in a dynamic era of climactic and environmental change. Harmful Algae. 2012; 3-17

4. Heinze R. A bio test for hepatotoxins using primary rat hepatocytes. Phycologia, 35 (Supplement). 1996; 89-93

5. Carmichael WW. The Cyanotoxins. In: Callow JA(ed), Advances in Botanical Research, Academic press, London, UK. 1997; 27:211-56.

6. Chorus I, Bartram, J (Eds).Toxic cyanobacteria in water: a guide to their public health consequences, monitoring, and management. London: E \& FN Spon.1999.

7. Sukenik A, Quesada A, Salmaso N. Global expansion of toxic and nontoxic cyanobacteria: effect on ecosystem functioning. Biodiversity and Conservation. 2015; 24(4): 889-908.

8. http://healthvermont.gov/enviro/bg_algae/bgalgae.aspx (2005). Bluegreen algae in lake Champlain.

9. Dantas EW, Moura AN, Bittencourt-Oliveria MC. Cyanobacterial blooms in stratified and de stratified eutrophic reservoirs in semi-arid region of Brazil. An. Acad. Bras. Cienc. 2011; 83:1327-1338.

10. Funari E, Testai E. Human health risk assessment related to cyanotoxins exposure. Crit. Rev. Toxicol.2008; 38: 97-125.

11. Swoboda UK, Dow CS, Chaivimol J, Smith N, Pound BP. Alternatives to the mouse bioassay for cyanobacterial toxicity assessment. In: G.A. Codd, T.M. Jefferies, C.W. Keevil and E. Potter (Eds) Detection Methods for Cyanobacterial Toxins, Special Publication No. 149, The Royal Society of Chemistry, Cambridge. 1994; 106-110.

12. http://www.science.org.au/nova/017/017key.htm (2009). Toxic algal blooms - a sign of rivers under stress.

13. Levine S. Interview: University of Vermont on March 23.2010.

14. Pflugmacher S. Possible allelopathy effects of cyanotoxins, with reference to microcystin-LR, in aquatic ecosystems. Environ. Toxicol. 2002; 17:407-413

15. Thomas J. Gonzalves EA. Thermal algae of Western India: VII. Algae of the hot springs at Rajapur. Hydrobiologia. 1965; 26: 66-71.

16. Jha M. Hydrobiological studies on Surajkund and Chandramakund, hot springs of Rajgir, Bihar India. Int. Rev. Gesamten Hydrobiol. 1992; 77: 435-443

17. Jha M, Kumar HD. Cyanobacterial flora and physicochemical properties of Saptadhara and Brahma Kund hot springs of Rajgir, Bihar, India. Nova Hedwigia. 1990; 50: 529-534

18. Bhattacharya S, Roy S, Ray S. Species composition of cyanobacterial component of mats collected from two hot springs of West Bengal, India - first report. Phykos. 2016; 46 (1): 32-39.

19. Jana BB. Seasonal periodicity of plankton in a freshwater pond in West Bengal, India. Int. Revueges Hydrobiol. 1973; 58: 127-143.

20. Debnath M, Mandal NC, Ray S. The Study of Cyanobacterial Flora from geothermal springs of Bakreswar, West Bengal, India. Algae. 2009; 24(4): 129-138

21. Matsunaga S, Moore RE, Niemszura WP. Anatoxin-a(S), a potent anticholinesterase from Anabaena flos-aquae. J. Am. Chem. Soc. 1989; 111: 8021-8023.

22. Roy S, Bhattacharya S, Debnath M, Ray S. Diversity of cyanobacterial flora of Bakeware geothermal spring, West Bengal, India-II. Algol. Stud.2015; 147: 29-44.

23. Roy S, Debnath M, Ray S. Cyanobacterial flora of the geothermal spring at Panifala, West Bengal, India. Phykos.2014; 44 (1): 1-8.

24. Carmichael WW. Cyanobacteria secondary metabolites-the cyanotoxins. Journal of Applied Bacteriology. 1992; 72(6):445-459.

25. Codd GA. Cyanobacterial toxins, the perception of water quality, and periodization of eutrophication control. Ecol. Eng. 2000; 16: 51-60.

26. Wiegand C, pflugmacher S. Eco toxicological effects of selected cyanobacterial secondary metabolites: a short review. Toxicol. Appl. Pharmacol. 2005; 203: 201-218.

27. Chorus I, Falconer IR, Salas HJ, Batram J. Health risks caused by fresh water cyanobacteria in recreational waters. J Toxicol Environ. Health Part B. 2000; 3:323-47.

28. Ferrao-Filho A da S, Kozlowsky-Suzuki B. Cyanotoxins: Bioaccumulation and Effects on Aquatic Animals. Marine Drugs. 2011; 9(12): 2729 2772.

29. Jamal Al, Tebrineh, Troco Kaan Mihali, Francesco Pomati, Brett A, Neilan. Detection of Saxitoxin-Producing Cyanobacteria and
Anabaena circinalis in Environmental Water Blooms by Quantitative PCR. Applied and environmental microbiology.2010; 76: 7836-7842.

30. Lawrence JF, Menard C, Cleroux C. Evaluation of pre chromatographic oxidation for liquid chromatographic determination of paralytic shellfish poisons in shellfish. J. AOAC Int.1995; 78: 514-520.

31. An J, Carmichael WW. Use of a colorimetric protein phosphatase inhibition assay and enzyme linked immuno sorbent assay for the study of microcystins and nodularins. Toxicon. 1994; 32:1495-1507.

32. Honkanen RE, Zwiller J, Moore RE, Daily SL, Khatra BS, Dukelow M, et al. Characterization of microcystin-LR, a potent inhibitor of type 1 and type 2A protein phosphatizes. Biol. Chem. 1990; 265:1940119404.

33. Carmichael WW. "Toxins of freshwater algae," in Handbook of Natural toxins, Marine toxins and Venoms.1998; 3:121-147.

34. Devlin JP, Edwards OE, Gorham PR, Hunter NR, Pike RK, Starvic B. Anatoxin-a, a toxic alkaloid from Anabaena flos-aquae NRC-44h. Can.J.Chem.1997; 55:1367-1371

35. Van Apeldoorn ME, van Egmond HP, Speijers GJA, Bakker GJI. Toxins of cyanobacteria. Molecular Nutrition \& Food Research. 2007; 51(1): 7-60

36. Strichartz G, Rando T, Hall S, Gitschier J, Hall L, Magnani B, et al. On the mechanism by which saxitoxin binds to and blocks sodium channels. Ann. N.Y. Acad. Sci. 1986; 479: 96-112.

37. Su Z, Sheets M, Ishida H, Li F, Barry WH. Saxitoxin blocks L-Type/Ca. J. Pharmacol. Exp. Therapeut. 2004; 308: 324-329

38. Mankiewicz J, Malgorzata TM, Walter Z, Maciej ZM. Natural toxins from cyanobacteria. Acta Biol. Cracovien. Ser. Bot. 2003; 45:9-20.

39. Stewart I, Schluter P, Shaw G. Cyanobacterial lipopolysaccharides and human health-A review. Environ. Health. 2006; 5:7.

40. Mayer AMS, Clifford JA, Aldulescu M, Frenkel JA, Holland MA, Hall ML, Glaser KB, Berry J. Cyanobacterial Microcystis aeruginosa lipopolysaccharide elicits release of superoxide anion, thromboxane B2, cytokines, chemokines and matrix metalloproteinase- 9 by rat microglia. Toxicol. Sci. 2011; 121:63-72.

41. Namikoshi M, Rinehart KL, Sakai R. Structures of three new cyclic heptapeptide hepatotoxins produced by the cyanobacterium (bluegreen algae) Nostoc sp. J Org Chem. 1990; 55:6135-9.

42. Carmichael WW. Health effects of toxin producing cyanobacteria: "the cyanoHABs". Hum Ecol Risk Assess. 2001; 7: 1393-1407.

43. Van der Merwe D. Cyanobacterial (Blue-Green Algae) Toxins. Handbook of Toxicology of Chemical Warfare Agents. 2015: 421-429.

44. Cianca RCC, Pallares MA, Barbosa RD, Adan LV, Martins JML, GagoMartínez A. Application of precolumn oxidation HPLC method with fluorescence detection to evaluate saxitoxin levels in discrete brain regions of rats. Toxicon. 2007; 49(1):89-99.

45. Backer L, Landsberg J, Miller M, Keel K, Taylor T. Canine Cyanotoxin Poisonings in the United States (1920s-2012): Review of Suspected and Confirmed Cases from Three Data Sources. Toxins. 2013; 5(9), 1597-1628.

46. Agarwal MK, Bagchi D, Bagchi SN. Acute inhibition of protease and suppression of growth in zooplankter, Moina macrocopa, by Microcystis blooms collected in Central India. Hydrobiologia. 2001; 464:37-44

47. Pflugmacher S. Promotion of oxidative stress in the aquatic macrophyte Ceratophyllum demersum during biotransformation of the cyanobacterial toxin microcystin-LR. Aquatic Toxicology. 2004; 70(3): 169-178.

48. Juhel G, Davenport J, O'Halloran J, Culloty SC, Ramsay RM, James KJ, Furey A, Allis O. Pseudodiarrhoea in zebra mussels, Dreissena polymorpha (Pallas), exposed to microcystins. J. Exp. Biol. 2006; 209: 810-816.

49. Cox PA, Banack SA, Murch SJ, Rasmussen U, Tien G. Diverse taxa of cyanobacteria produce b-n-methylamino-l-alanine, a neurotoxic amino acid. Proceedings of the National Academy of Science. 2005; 102: 27.

50. Dadheech PK, Raisinghani G, Trivedi PC. Phycotoxins- a status report in: algal biotechnology. F.C. Trivedi (ed.), popular printers, Raj., India 2001 ; 383- 389.

51. Sivonen K. Cyanobacterial toxins and toxin production. Phycol.1996; 35:12-24

52. Bagchi SN. Cyanobacterial lipopolysaccharides and human health -a review. J. Sci. and In.Res. 1999; 55:715-727.

53. Testai E, Buratti FM, Funari E, Manganelli M, Vichi S, Arnich N, Sialehaamoa A. Review and analysis of occurrence, exposure 
and toxicity of cyanobacteria toxins in food. EFSA Supporting Publications. 2016; 13(2):1-309.

54. Carmichael, W.W. The toxins of cyanobacteria. Sci Am. 1994; 270(1): 78-86.

55. Anadotter H, Cronberg G, Lawton LA, Hansson HB, Gothe U, Skulberg OM. An extensive outbreak of gastroenteritis associated with the toxic cyanobacterium Planktothrix agardii (Oscillatoriales, Cyanophyceae) in Scania, South Sweden, In Chorus, I. (ed.) Cyanotoxins, occurrence, causes, and consequences. Springer, Berlin, Germany.2001: 200-208.

56. Chang KY, Wang W, Wu JJ, Liu L, Theodoratou E, Car J, iddleton L, Russ TC, Deary IJ, Campbell H., et al., Epidemiology of Alzheimer's disease and other forms of dementia in China, 1990-2010. A Systematic review and analysis. Lancet. 2013; 381:2016-2013.

57. Mundt S, Kreitlow S, Nowotny, A, Effmert, U. Biochemical and pharmacological investigations of selected cyanobacteria. International Journal of Hygiene and Environmental Health. 2001; 203(4): 327-334.

58. Mundt S, Kreitlow S, Jansen R. Fatty acids with antibacterial activity from the cyanobacterium Oscillatoria redeksei HUB 051. Journal of Applied Phycology. 2003; 15(2/3): 263-267.

59. Takenaka S, Watanabe MF. Microcystin LR degradation by Pseudomonas aeruginosa alkaline protease. Chemosphere. 1997; 34: 749-757.

60. Massey IY, Yang F. A Mini Review on Microcystins and Bacterial Degradation. Toxins, 2020;12(4):268

61. Ibelings BW, Havens K, Codd GA, Dyble J, Landsberg J, Coveney M, Fournie JW, Hilborn ED. Ecosystem Effects Group. In Cyanobacterial Harmful Algal Blooms: State of the Science and Research Needs; Hudnell, H.K., Ed. Springer Science: New York. 2008; 619 (31): 656-674.

62. Beattie KA, Ressler J, Wiegand C, Krause E, Codd GA, Steinberg CEW, Pflugmacher S. Comparative effects and metabolism of two microcystins and nodularin in the brine shrimp Artemia salina. Aquatic Toxicology. 2003; 62(3): 219-226.

63. Kiviranta J, Abdel-Hameed A, Sivonen K, Niemela SI, Carlberg G. Toxicity of cyanobacteria to mosquito larvae: screening of active compounds. Environ. Toxicol Water Qual. 1993; 8:63-71.

64. Harada KI, Kondo F, Lawton L. Laboratory analysis of cyanotoxins. In I. Chorus and J. Bartram (Eds.), Toxic cyanobacteria in water: A Guide to their public health consequences, monitoring, and management. 1999; 369-405.

65. Delaney JM, Wilkins RM. Toxicity of Microcystin-LR Isolated from Microcystis aeruginosa against various Insect species. Toxicon. 1995; 33: 771-778.

66. Marsalek B, Blaha L. Comparison of 17 bio tests for detection of cyanobacterial toxicity. Environmental Toxicology, 2004; 19(4): 310-317.

67. Xianchong Z, Wilfredo E, Spyridon P, Grace Z. $\beta$-N-Methylamino-LAlanine Induces Neurological Deficits and Shortened Life Span in Drosophila. Toxins. 2010; 2:2663-2679.

68. Botana LM, James K, Crowley J, Duphard J, Lehane M, Furey A. Phycotoxins: Chemistry and Biochemistry. Blackwell Publishing.2007.

69. Cook AC, Morris S, Reese RA, Irving SN. Assessment of fitness for purpose of an insect bioassay using the desert locust (Schistocerca gregaria $L$.) for the detection of paralytic shellfish toxins in shellfish flesh. Toxicon. 2006; 48(6): 662-771.

70. Pichardo S, Jos A, Zurita J, Salguero M, Camean AM, Rapetto G. Toxic effects produced by microcystins from a natural cyanobacterial bloom and a Microcystis aeruginosa isolated strain on the fish cell lines RTG-2 and PLHC-1. Arc. Environ. Contam. Toxicol. 2006; 51: 86-96.

71. Cembella AD, Milenkovic L, Doucette G, Fernandez M. In Vitro biochemical methods and mammalian bioassays for phycotoxins. In: G.M. Hallegraeff, D.M. Anderson and A.D. Cembella [Eds] Manual on Harmful Marine Microalgae, IOC Manuals and Guides No. 33, United Nations Educational, Scientific and Cultural Organization, Paris. 1995; 177-211.

72. Bhattacharya R, Rao PVL, Bhaskar ASB, Pant SC, Dube SN. Liver slice culture for Assessing hepatotoxicity of freshwater cyanobacteria. Hum. Exp. Toxicol. 1996; 15:105-110.

73. Ray S, Bagchi SN. Nutrients and $\mathrm{pH}$ regulate algaecide accumulation in cultures of cyanobacterium Oscillatoria latevirens. New Phytol. 2001; 149: 445-460.
74. Marwah JB, Shakila TM, Rao NS, Bagchi SN. Detoxification of a local Microcystis bloom by an algicidal antibiotic from Oscillatoria late-virens. Ind. J. Exp. Biol.1995; 33: 97-100.

75. Jellet JF, Marks LJ, Stewart JE, Dorey ML, Watson-Wright W, Lawrence JF. Toxic cyanobacteria in water: A guide to their public health consequences, monitoring, and management. Toxicon. 1992 30: 1143-1156

76. Gallacher S, Birkbeck TH. A tissue culture assay for direct detection of sodium channel blocking toxins in bacterial culture supernates. FEMS Microbiol. Lett. 1992; 92: 101-108.

77. Doucette GJ, Logan MM, Van Dolah FM, Ramsdell JS. In: JR Forbes[ed], Proceedings of the Fourth Canadian Workshop on Harmful Marine Algae, Can. Tech. Rep. Fish. Aquatic Sci. 1994; 2016; 9.

78. Chu FS, Huang X, Wei RD, Carmichael WW. Production and characterization of antibodies against microcystins. Appl. Environ Microbial. 1989; 55: 1928-1933.

79. Weller M. Immunoassays and Biosensors for the Detection of Cyanobacterial Toxins in Water. Sensors. 2013; 13(11): 15085-15112.

80. Pendleton P, Schumann R, Wong SH, Coloid J. Microcystin-LR Adsorption by Activated Carbon. Interf. Sci. 2001; 240: 1-8.

81. Ribau-Teixeira M, Rosa MJ. Integration of dissolved gas flotation and Nano filtration for $M$. aeruginosa and associated microcystins removal. Water Res. 2006; 40(19): 3612-3620.

82. Zhang G, Zang P, Wang B, Liu H. Ultrasonic frequency effects on the removal of Microcystis aeruginosa. UltrasonicsSonochem.2006; 13 (5):446-450.

83. Gijsbertsen- Abrahamse AJ, Schmidt W, Chorus I, Heijman SGJ. Water Res. 2006; 40(6): 1200-1209.

84. Meriluoto J, Gueimonde M, Haskard CA, Spoof L, Sjövall O Salminen S. Removal of the cyanobacterial toxin microcystin-LR by human probiotics. Toxicon. 2005: 46(1): 111-114.

85. Holst T, Jorgensen NOG, Jorgensen C, Johansen A. Degradation of microcystin in sediments at oxic and anoxic, denitrifying conditions. Water Res. 2003; 37: 4748-4760.

86. Maatouk I, Bouaicha N, Fontan D, Levi Y. Seasonal variation of microcystin concentrations in the Saint-Caprais reservoir (France) and their removal in a small full scale treatment plant. Water Research. 2002: 36:2891-2897.

87. Falconer IR, Humpage AR. Health risk assessment of cyanobacterial (bue-green algal) toxins in drinking water. Int J Res Public Health. 2005; 2: 43-50.

88. Welker M, Fastner J, Erhard M, von Dohren H. Applications of MALDITOF MS analysis in cyanotoxin research. Environmental Toxicology. 2002; 17(4): 367-374.

89. Falconer IR. Measurement of toxins from blue-green algae in water and Foodstuffs. In: I.R. Falconer (Ed.) Algal Toxins in Seafood and Drinking Water. Academic Press, London. 1993; 165-175.

90. Kiviranta J, Sivonen K, Niemela SI. Detection and toxicity of cyanobacteria by Artemia salina bioassay. Environ. Toxicol. Water Qual. 1991; 6: 423-426.

91. Shian Min Liau. The effect of prior exposure to toxic cyanobacteria on the survival and cyanotoxin accumulation in Daphnia Carinata. B (Eng) Environmental.2015; 4: 1-101.

92. Kozma A. Inter laboratory trial using Thamnotox kit for detecting cyanobacterial toxins. Abstract, VIII International Conference on Harmful Algae, Vigo, Spain. 1997; 114.

93. Turell MJ, Middlebrook JL. Mosquito inoculation: An alternative bioassay for toxins. Toxicon. 1988; 26(11): 1089-1094.

94. Chorus I. Germany: approaches to assessing and managing the cyanotoxin risk. Federal Environment Agency, Germany. Federal Environment Agency, Germany. 2012; 63: 1-152

95. McElhiney J, Lawton LA, Edwards C, Gallacher S. Development of a bioassay employing the desert locust (Schistocerca gregaria) for the detection of saxitoxin and related compounds in cyanobacteria and shellfish. Toxicol. 1998; 36: 417-420.

96. Ross MR, Siger A, Abbott C. The house fly: An acceptable subject for paralytic shellfish toxin bioassay. In: D.M. Anderson, J.A.W. White and D.G. Baden (Eds) Toxic Dinoflagellates: Proceedings of the Third International Conference on Toxic Dinoflagellates. Elsevier, Amsterdam. 1985: 433-438.

97. Lawton LA, Edwards C, Codd GA. Extraction and High Performance Liquid Chromatographic Method for the Determination of Microcystins in Raw and Treated Water. Analyst. 1994; 119: 1525-1530. 
98. Dierstein R, Kaiser I, Weckesser J. Inhibition of Prodigiosin Formation in Serratia marcescens by Extracts of Toxic Cyanobacteria. Systematic and Applied Microbiology. 1989; 12(3): 244-248.

99. Moore C.E, Juan J, Lin Y, Gaskill CL, Puschner B. Comparison of Protein Phosphatase Inhibition Assay LC-MS/MS for Diagnosis of Microcystin Toxicosis in Veterinary Cases. 2016; 3:1-16.

100. Holmes CFB. Liquid chromatography-linked protein phosphatase bioassay; a highly sensitive marine bio screen for okadaic acid and related diarrhetic shellfish toxins. Toxicon. 1991; 29(4/5):469-477.

101. Hilborn ED, Carmichael WW, Yuan M, Azevedo SMFO. A simple colorimetric method to detect biological evidence of human exposure to microcystins. Toxicon. 2005; 46(2): 218-221.

102. Mahmood NA, Carmichael WW. Anatoxin-a(s), an anticholinesterase from the cyanobacterium Anabaena flos-aquae NRC-525-17. Toxicon. 1987; 25(11): 1221-1227.

103. Gaget V, Lau M, Sendall B, Froscio S, Humpage AR. Cyanotoxins: Which detection technique for an optimum risk assessment? Water Research. 2017; 118:227-238.

104. Samdal IA, Ballot A, Lovberg KE, Miles CO. Multihapten Approach Leading to a Sensitive ELISA with Broad Cross-Reactivity to Microcystins and Nodularin. Environmental Science \& Technology. 2014; 48(14): 8035-8043.

105. Ueno Y, Nagata S, Tsutsumi T, Hasegawa A, Watanabe MF, Park HD, Chen GC, Chen G, Yu Z. Detection of microcystins, a blue-green algal hepatotoxin, in drinking water sampled in Haimen and Fusui, Endemic areas of primary liver cancer in China, by highly sensitive immunoassay. Carcinogenesis.1996; 17:1317-1321.

106. Micheli L, Di Stefano S, Moscone D, Palleschi G, Marini S, Coletta M, et al. Production of antibodies and development of highly sensitive formats of enzyme immunoassay for saxitoxin analysis. Analytical and Bioanalytical Chemistry. 2002; 373(8): 678-684.

107. Fladmark KE, Serres MH, Larsen NL, Yasumoto T, Aune T, Doskeland SO. Sensitive detection of apoptogenic toxins in suspension cultures of rat and salmon hepatocytes. Toxicon. 1998; 36(8): 1101-1114

108. Pouchus YF, Amzil Z, Baut CM.L, James KJ, Verbist JF. Specificity of the test based on modification of cell morphology for detection of lipophilic inhibitors of protein phosphatases. Toxicon. 1997; 35(7): 1137-1142.

109. Kogure K, Tamplin ML, Simidu U, Colwell RR. A tissue culture assay for tetrodotoxin, saxitoxin and related toxins. Toxicon. 1988; 26(2):191-197.

110. Agarwal MK, Bagchi SN, Kleiner D, Mohanty P. In: Protocols on algal and cyanobacterial research. (Eds), Narosa Publishers, New Delhi. 2010: 281-288.

111. Martin J, Valler D. Green "diversity screening versus focused screening in drug discovery" Drug Discovery Today. 2000; 5 (7).

112. Harada KI, Kondo F, Lawton L. In: Chorus, I and Bartram, J [eds], World HealthOrganization. 1999.

113. Aranda-Rodriguez R, Kubwabo C, Benoit FM. Extraction of 15 microcystins and nodularin using immune affinity columns. Toxicon. 2003; 42(6): 587-599.

114. Birbeck J, Westrick J, O’Neill G, Spies B, Szlag D. Comparative Analysis of Microcystin Prevalence in Michigan Lakes by Online Concentration LC/MS/MS and ELISA. Toxins. 2019; 11(1): 13

115. Pelander A, Ojanpera I, Lahti K, Niinivaara K, Vuori E. Visual detection of cyanobacterial hepatotoxins by thin-layer chromatography and application to water analysis. Water Research. 2000; 34(10): 2643-2652.

116. Sano T, Nohara K, Shirai F, Kaya KA. Method of micro detection of total microcystin content in water bloom of cyanobacteria (blue-green algae). Int.J. Environ. Analyte Chem. 1992; 49: 163-170.

117. Erhardt $M$, von Dohren $H$, Jungblut P. Rapid typing and elucidation of new secondary metabolites of intact cyanobacteria using MALDI-TOF mass spectrometry. Nature Biotech. 1997; 15: 906-909.

118. Maizels M, Budde WL. A LC/MS Method for the Determination of Cyanobacteria Toxins in Water. Analytical Chemistry. 2004; 76(5): 1342-1351.

119. Botes DP, Tuinman AA, Wessels PL, Viljoen CC, Kruger H, Williams DH, Santikarn S. The structure of cyanoginosin-LA, a cyclic heptapeptide toxin from the cyanobacterium microcystis aeruginosa. J. Chem. Soc., Perkin Transactions. 1984; 1:2311-2318.

120. James KJ, Furey A, Sherlock IR, Stack MA, Twohig M, Caudwell FB, Skulberg OM. Sensitive determination of anatoxin-a, homoanatoxin-a and their degradation products by liquid chromatography with fluorimetric detection. Journal of Chromatography A. 1998; 798(1-2): 147-157.

121. Smith RA, Lewis D. A rapid analysis of water for anatoxin-a, the unstable toxic alkaloid from Anabaena flos-aquae, the stable nontoxic alkaloids left after bio reduction and related an amine which may be nature's precursor to anatoxin-a. Vet. Human Toxicol. 1987; 29:153-154.

122. Stevens DK, Krieger RI. Analysis of anatoxin-a by GC/ECD. J. Analyt. Toxicol.1988; 12:126-131.

123. Harada KI, Nagai $H$, Kimura $Y$, Suzuki M, Park $H$, Watanable MF, Luukkainen R, Sivonen K, Carmichael W.W. Liquid chromatography/ mass spectrometric detection of anatoxin-a, a neuroanatoxin from cyanobacteria, Tetrahedron. 1993; 49: 9251, 1993b.

124. Bouma-Gregson K, Kudela RM, Power ME. Widespread anatoxin-a detection in benthic cyanobacterial mats throughout a river network. PLOS ONE. 2018; 13(5).

125. Harada HI, Ohtani, Iwamoto K, Suzuki M, Watanable M, Terao K Isolation of cylindrospermopsin from a cyanobacterium Umezakianatans and its screening methods. Toxicon. 1994; 32(1): 73-84.

126. Hawkins PR, Chandrasena NR, Jones GJ, Humpage AR, Falconer IR. Isolation and toxicity of Cylindrospermopsis racisborskii from an ornamental lake. Toxicon. 1997: 35: 341-346.

127. Hiskia A, Spoof L, Kaloudis T, Meriluoto J. Determination of Cyanotoxins by High-Performance Liquid Chromatography with Photodiode Array. Handbook of Cyanobacterial Monitoring and Cyanotoxin Analysis. 2017; 203-211.

128. Oshima Y, Hasegawa M, Yasumoto T, Hallegraeff G, Blackburn S Dinoflagellate Gymnodinium catenatum as the source of paralytic shellfish toxins in Tasmanian shellfish. Toxicon. 1987; 25(10): 1105-1111.

129. Quilliam MA, Thomas BA, Scott GJ, Siu KWM. Ion- spray mass spectrometry of marine neurotoxins. Rapid Commun. Mass spectrum. 1989: 3:145.

130. Hines HB. Electrospray ionization of selected low-molecular-weight natural biotoxins. Biol Mass Spectrum. 1993; 22: 243-246.

131. Pleasance S, Thibault P, Kelly J. Comparison of liquid-junction and coaxial interfaces for capillary electrophoresis-mass spectrometry with application to compounds of concern to the aquaculture industry. J. Chromatog. 1992; 591: 325-339.

132. Schofield T. Dissolved air flotation in drinking water production. Water Sci. Technol. 2001; 43(8): 9-18.

133. Van Wichelen J, Vanormelingen P, Codd GA, Vyverman W. The common bloom-forming cyanobacterium Microcystis is prone to a wide array of microbial antagonists. Harmful Algae. 2016; 55: 97-111. 